\title{
1 Marine Protected Areas show low overlap with projected distributions of 2 seabird populations in Britain and Ireland
}

3 Emma Jane Critchley ${ }^{\text {a c }}$, W. James Grecian ${ }^{\text {b } ~}$, Adam Kane ${ }^{\text {a }}$, Mark J. Jessopp ${ }^{\text {a c }}$, \& John L.

4 Quinn $^{\text {a }}{ }^{* *}$

$5 \quad{ }^{a}$ School of Biological, Earth and Environmental Sciences, University College Cork, Ireland

$6 \quad{ }^{\mathrm{b}}$ Sea Mammal Research Unit, Scottish Oceans Institute, University of St Andrews, KY16 8LB, UK

$7 \quad{ }^{\mathrm{c}}$ MaREI Centre, Environmental Research Institute, University College Cork, Ireland

$8 \quad{ }^{\alpha}$ Co-first author

$9{ }^{\S}$ Co-senior author

10 *Corresponding authors; e.critchley@umail.ucc.ie; j.quinn@ucc.ie

\section{Abstract}

Marine Protected Areas (MPAs) are an important tool for the conservation of seabirds. However, mapping seabird distributions using at-sea surveys or tracking data to inform the designation of MPAs is costly and time-consuming, particularly for far-ranging pelagic species. Here we explore the potential for using predictive distribution models to examine the effectiveness of current MPAs for the conservation of seabirds, using Britain and Ireland as a case study. A distance-weighted foraging radius approach was used to project distributions at sea for an entire seabird community during the breeding season, identifying hotspots of highest density and species richness. The percentage overlap between distributions at sea and MPAs was calculated at the level of individual species, family group, foraging range group (coastal or pelagic foragers), and conservation status. On average, $32.5 \%$ of coastal populations and $13.2 \%$ of pelagic populations overlapped with MPAs, indicating that pelagic species (many of which are threatened) are likely to have significantly less coverage from protected areas. We suggest that a foraging radius approach provides a pragmatic and rapid method of assessing overlap with MPA networks for central place foragers. It can also act as an initial tool to identify important areas for potential designation. This would be particularly useful for regions throughout the world with limited data on seabird distributions at sea and limited resources to collect this data. Future assessment for marine conservation management should account for the disparity between coastal and pelagic foraging species to ensure that wider-ranging seabirds are afforded adequate levels of protection.

Keywords: 


\section{Introduction}

34

Even though most of the world's oceans continue to be impacted by humans (Game et al., 2009; Halpern, 2008), just over 4\% of their area is currently protected (UNEP-WCMC and IUCN, 2016). There is an urgent need to speed up the identification and designation of Marine Protected Areas (MPAs) given that one of the Aichi targets is to protect $10 \%$ of the oceans by 2020 (Secretariat of the Convention on Biological Diversity, 2014; Watson et al. 2014). Seabirds provide an important focus for the development of protected areas. As is true for all marine top-predators, they are threatened by a suite of impacts, particularly from fisheries and pollution, and are in urgent need of protection in many parts of the world (Croxall et al., 2012). The use of Important Bird Areas (IBAs) to delineate candidate MPAs for the conservation of seabirds globally has been encouraged by conservation bodies (BirdLife International, 2010; Lascelles et al., 2012). In the European Union (EU), as of 2014, $59 \%$ of areas identified as marine IBAs have been designated as either Special Protected Areas (SPAs) or Special Areas of Conservation (SACs) (BirdLife International, 2014). However, only 3.9\% of the total EU marine area is designated for marine SPAs, similar to global levels of coverage, and much lower than the $12.5 \%$ designated for terrestrial SPAs (Ramirez et al., 2017). One of the reasons that designation of MPAs in Europe and elsewhere has been slow is that the costs and challenges of identifying biodiversity hotspots are prohibitive for many marine regions. In this paper we develop a simple modelling approach that can be used to quickly identify areas of importance for seabird communities, and assess coverage by existing protected areas.

Protected areas for seabirds usually focus on the locations of important breeding colonies, either at the nesting sites themselves or through seaward extensions in the waters immediately surrounding the colony (BirdLife International, 2010). The use of IBAs based on short-range colony extensions works well for coastal foragers (McSorley et al., 2003; Wilson et al., 2009) - especially when individual colonies hold a high proportion of the total population - as the designated protected areas often encompass the majority of the colony's range. These coastal MPAs, however, are less effective for protecting pelagic species, whose ranges cover large areas, often crossing national boundaries (Game et al., 2009; Grémillet and Boulinier, 2009; Hyrenbach et al., 2000). At the same time, pelagic species are more threatened than coastal species, and many of the greatest threats, such as by-catch, occur in feeding grounds offshore (Croxall et al., 2012). Designation of MPAs in these areas, using a multispecies and multi-colony approach, can help ensure appropriate conservation management practices are put in place (Ballard et al., 2012; Nur et al., 2011; Ronconi et al., 2012).

Ideally identifying important areas for seabirds should be done with empirical data since foraging areas are patchy and difficult to locate, especially for pelagic species. For example, recent work has identified multiple global hotspots for pelagic species using existing tracking data (Lascelles et al., 2016). In general, however, tagging studies rarely collect information from more than one or two 
colonies or species at a time (but see Dean et al., 2015 and Wakefield et al., 2017), and data is generally only collected for a limited time span within seasons, across seasons, and across years. Large-scale studies of multiple species from multiple colonies take a long time and enormous resources (Block et al., 2011; Grecian et al., 2016). Furthermore, although empirical data from aerial and ship surveys are highly valuable, even the European Seabirds at Sea database (amassing data from over 35 years) contains large gaps in coverage (Dunn, 2012; Stone et al., 1995). Replication within areas over time is limited and yet foraging areas can shift from year to year (Robertson et al., 2014), variability that is likely to increase with climate change (Grémillet and Boulinier, 2009). In many circumstances, therefore, predictive distribution modelling is likely to be a more cost effective and realistic approach for identifying biodiversity hotspots at an ecosystem level.

In recent years, an approach using colony census data together with foraging ranges of seabirds, who are central place foragers during the breeding season, has been used to identify hotspots for individual species (Grecian et al., 2012; Soanes et al., 2016; Thaxter et al., 2012). Predicted distributions from these models correlate well with GPS tracking and at-sea survey data for northern gannets (Morus bassanus) in Britain and Ireland (Grecian et al., 2012), and six other species globally (Soanes et al., 2016). Use of the method led to designation of the first MPA in Namibia for African penguins (Spheniscus demersus) (Ludynia et al., 2012). The foraging range approach is one of the recommended methods for identifying marine IBAs (BirdLife International, 2010), and may be particularly useful in regions where distribution data is lacking and the cost of at-sea surveys would be prohibitive, such as the South East Atlantic or South West Pacific (Kot et al., 2010). This relatively simple method predicts a baseline distribution which can then be further refined using data on species specific foraging behaviours or other ecological factors to identify concentrated patches. However, it has yet to be applied on a large regional scale, for multiple colonies or for multiple species.

In this study we use the foraging range approach to produce projected distributions for all seabird species breeding in Britain and Ireland, identifying potential hotspots of high abundance. We then assess overlap with marine protected areas at a species, family and foraging range group (coastal or pelagic foragers) level. The location of at-sea distribution hotspots will vary according to colony location and we hypothesise that the level of coverage by protected areas will be higher for coastal species, which would be better covered by seaward colony extensions than pelagic species. Finally, we discuss the validity and potential for using the foraging range approach globally.

\section{Methods}

\subsection{Data collation}

Open-access data for all seabird species breeding in Britain and Ireland were used to generate projected distributions (see Table 1). Data on colony locations and population sizes were extracted from the JNCC Seabird Monitoring Programme (SMP) Database [at www.jncc.gov.uk/smp] to create 
individual data sets for the 25 species that breed in Britain and Ireland. Most colonies have been counted at least as recently as the Seabird 2000 survey (Mitchell et al., 2004), however colony counts for some species were incomplete and were supplemented with information from BirdWatch Ireland and RSPB annual reports where available (Doyle et al., 2015; Daly et al., 2015; Burke et al., 2015). In the final dataset used for this study $\sim 3 \%$ of colonies have not been censused in the last 30 years, these are all mainly colonies in remote regions. Additional colony data for locally threatened species (e.g. roseate tern) were provided with the permission of RSPB, however these distributions are not included here due to the sensitive nature of the data.

Maximum foraging range estimates were taken from reviews (Thaxter et al., 2012 and Jovani et al., 2015), and more recent studies (Kane, A. Pers. Comm.; Thaxter et al., 2013; Wakefield et al., 2013) (see Table 1). The best available estimate was taken for each species, either from direct (e.g. GPS tracking), indirect (e.g. time-activity data loggers) or survey data (boat, aerial, or land-based). In general, values for foraging range obtained from direct and indirect estimates do not vary significantly (Camphuysen et al., 2006; Thaxter et al., 2012) suggesting that where tracking data is not available other methods can provide useful estimates of foraging ranges. Maximum foraging range was used to ensure that all potential usage areas were accounted for, even though densities of birds at the edge of the ranges would be very low. Whilst some studies using the foraging radius approach have used the mean of all maximum foraging ranges, maximum foraging ranges from multiple colonies are not available for all species in Britain and Ireland. In reality maximum distances are likely to vary quite a lot around the coasts and the use of the maximum recorded foraging range here is a conservative way to incorporate all of this variation. The validity of this approach is considered further in the discussion, including selected post hoc analyses using mean maximum foraging ranges.

\subsection{Generating projected distributions}

Using the steps below, and as set out in Figure A.1 in the supplementary information, projected at-sea distributions for individual colonies were generated following a similar process to Grecian et al. (2012). Maps of colony locations and population size can be seen in Figure 1a for sample coastal and pelagic species, and in the supplementary information for all species. The distribution maps are plotted on a $5 \times 5 \mathrm{~km}$ grid and show the number of individuals predicted to occur in each grid square, if $50 \%$ of the colony is foraging at-sea at a given time. This accounts for the assumption that on average, one half of a breeding pair will remain at the nest at any one time (e.g. during incubation and early chick rearing). The proportion of the population at sea (and subsequent numbers of birds in each grid square) at any one time will vary with both time of day and season. However, the relative importance of each grid square will remain the same and the same hotspots will be identified.

Step 1: Create a grid surface ( $5 \mathrm{x} 5 \mathrm{~km}$ grid) where values in each grid square represent the distance from the focal colony. 
Step 2: Plot colony centred radii based on maximum foraging range for each species. Any land occurring within the foraging area is excluded to define the total available foraging area for the colony. Birds were assumed to only travel over sea, and therefore land was made too expensive to cross in the model. Maximum foraging range was used to ensure coverage of the majority of a colony's foraging area. However, it can be assumed that due to additional behaviours the individuals from a colony will not be spread evenly across this area, and steps 3 and 4 correct for this.

Step 3: Invert and normalise the grid square values, so that they all have a value of between 0 and 1 with the highest values being found closest to the colony. These values are now the probability of a bird occurring in a given grid square, with probability decreasing linearly as distance from colony increases.

Step 4: Weight values in each grid square by the inverse log distance from the colony. This weights the areas closer to the colony of higher importance to account for non-foraging behaviours such as washing/preening or rafting (Wilson et al., 2009).

Step 5: Normalise values so that the sum of all grid squares is equal to 1 i.e. $100 \%$ of the at-sea population.

Step 6: Multiply proportions in each grid square by the total at-sea population (e.g. 50\% of the breeding population). This generates the predicted number of individuals occurring per grid square.

These steps were repeated for each individual colony and the distributions were then summed to generate a projected distribution map for the entire region (e.g. Britain and Ireland). A number of colonies in the dataset were located at a further distance inland than the reported maximum foraging range, therefore at-sea distributions were not created for these colonies. Most of these colonies were gulls (see Table 1 for specifics) and can be presumed to be mainly foraging over land (Rock 2016). Table 1 contains details of all of the coastal colonies included in the analysis.

Distributions were summed across species to assess the overall distribution of all species collectively, as well as eight family groups (e.g. terns, gulls, see Appendix B for full list) and two foraging range groups (coastal vs. pelagic foragers). For the purpose of this study species with a maximum foraging range of less than $75 \mathrm{~km}$ were defined as coastal and those with a maximum foraging range of $75 \mathrm{~km}$ or greater were defined as pelagic. There is no clear bimodal distinction between the two groups, however a cut off of $75 \mathrm{~km}$ generates groups of comparable size (Coastal $=12$; Pelagic $=13)$. The groupings also reflect the foraging ecology of the species, with Terns, Cormorants and most Gulls in the coastal group and species such as gannet and Manx shearwater that are known to occur well offshore in the pelagic group. 
In order to assess species richness from the grouped distribution, the number of species occurring within each grid square was calculated.

\subsection{Calculating protected area overlap}

173 Coverage of protected areas for individual species was quantified by calculating the percentage of the at-sea population estimated to occur within the spatial boundaries of a protected area. Spatial data for the boundaries of all protected areas with marine components in Britain and Ireland were obtained from the World Database on Protected Areas (IUCN and UNEP-WCMC, 2016). These were then split into three types: (1) Special Protected Areas (SPAs); (2)

(2) OSPAR convention (Convention for the Protection of the Marine Environment of the Marine Environment of the North-East Atlantic) MPAs; and (3) all protected areas (PAs) combined (also including SPAs and OSPAR MPAs). This allowed a comparison between protected area types which often include seabirds as their designation criteria to meet EU requirements (SPAs which are specifically for protection of birds and OSPAR MPAs which are designated for a wider range of taxa) and all other protected area types recognised in Britain and Ireland. All individual protected area polygons were merged to generate one polygon for each type (e.g. one polygon for all SPAs) to avoid double-counting birds that occurred in grid squares where protected areas overlap.

A Wilcoxon rank sum test was used to assess the difference in percentage overlap for (1) foraging group (coastal or pelagic) and (2) conservation status (Least Concern or Near Threatened and above). These comparisons were carried out for percentage overlap of SPAs, OSPAR MPAs and all PAs combined. All analyses were carried out in R version 3.2.1 (R Development Core Team, 2016). Maps of the distributions were created using the R package 'ggplot2' version 2.00 (Wickham 2009).

\section{Results}

Projected distributions for all seabird species breeding in the UK and Ireland individually (Figure 1b for a sample of species, and supplementary information for all species) and in family groups (Figure 1c for a sample of family groups, and supplementary information for all family groups) were generated. The distributions generated show the average number of individuals per $5 \times 5 \mathrm{~km}$ grid cell predicted to be at-sea during the breeding season.

197 Grouped distributions were produced for all coastal species (Figure 2a), all pelagic species (Figure 2b) and all species combined (Figure A.5, supplementary information). Hotspots of abundance for coastal species are spread around Britain and Ireland, with the east coast of Ireland, the south-east coast of England and the Shetland Islands shown as being particularly important. Conversely, for pelagic species, Scotland is of greatest importance. At the family level, considerable variation also occurs. For 
Procellariidae hotspots are clumped on the west coasts where they have easy access to distant foraging areas. A map of species richness was produced showing the potential number of species occurring within each grid square based on the projected distribution for all species combined (Figure 3).

Overlap between projected seabird distributions and currently designated protected areas (SPAs, OSPAR MPAs, and all PAs) ranged from under $7 \%$ of the at-sea population contained in all protected areas (European storm-petrel) to over 70\% of the at-sea population (Mediterranean gull) (Figure 4). See Table B.1 in the supplementary material for a breakdown of overlap by species and family group. Values are likely to vary with the time of day, but remain representative for the time period when the majority of foraging takes place.

Overall, the percentage of a population covered by a protected area was significantly higher for coastal species $($ mean $=32.5 \%)$ than for pelagic species $($ mean $=13.2 \%)(p<0.001$, Table 2$)$. This difference was also significant when considering SPAs (mean coastal $=18.1 \%$ and mean pelagic $=$ $2.4 \%, p<0.001$ ), or OPSAR MPAs (mean coastal $=25.5 \%$ and mean pelagic $=11.9 \%, p=0.001$ ) individually. Non-threatened species had a higher coverage from protected areas than threatened species (mean non-threatened $=25.0 \%$ and mean threatened $=14.3 \%$ ). This relationship was significant for overlap with SPAs ( $p=0.01$ ), but just fell short of significance at the $a=0.05$ level for overlap with OSPAR MPAs $(p=0.09)$ or all PAs combined $(p=0.07)$ (Table 2).

\section{Discussion}

\subsection{General patterns of distribution}

Projection based models using foraging ranges and colony sizes have previously been used to estimate and map densities of seabirds at sea for single or small numbers of species (Grecian et al., 2012; Ludynia et al., 2012; Soanes et al., 2016). Here we applied this approach for an entire seabird community in a major area for seabirds in Europe. Patterns of distribution varied remarkably between species. In particular a clear distinction is seen between hotspots for coastal versus pelagic species, which are reflected in the distribution of breeding colonies (Mitchell et al., 2004). Naturally the models show that abundance hotspots are located nearest the colonies or groups of colonies with the largest population sizes. Even though some seabirds will travel long distances away from the colony to forage, it should still follow that the largest colonies will be located where access to resources minimizes the cost of travel to reach resources (e.g. Sandvik et al., 2016), and where direct competition from other colonies is low (Furness \& Birkhead, 1984). This basic principle of optimal foraging means that a projection based model such as ours is well suited for capturing the majority of space use by central place foragers (Ashmole 1963). 
237 The analysis of overlap between protected areas and projected at-sea distributions found large 238 variation in coverage amongst species, ranging from 7\% (European storm-petrel) to 70\%

239 (Mediterranean gull) of at-sea population contained in protected areas. In particular, we found a 240 significantly higher proportion of coastal birds were covered by protected areas compared to pelagic 241 birds, many of which are threatened globally, suggesting that they are afforded better protection from 242 designated MPAs. This result is explained by the fact that most MPAs (particularly marine components of SPAs) are developed as extensions from the coast, often surrounding an important colony for a particular seabird species. This pattern occurred even though the projected distributions are weighted so that proportionally more birds are found closer to the colony than at the edge of their foraging ranges, which will affect pelagic foragers more heavily. It is clear that due to the large foraging ranges of pelagic species, coastal colony-centred marine protected areas will not provide sufficient coverage to adequately protect them (see Game et al. 2009 on the lack of pelagic protected areas). While OSPAR MPAs seem to afford better protection to pelagic species than SPAs, the percentage overlap is still significantly lower than for coastal species.

Our analyses also suggest that current marine SPAs afford better protection to species with a conservation status of 'Least Concern' compared to those ranked as 'Near Threatened' or above. The level of coverage is also higher for 'Least Concern' species in OSPAR MPAs and all MPAs combined, but not significantly so. This reflects the fact that all species ranked 'Near Threatened' or above are also pelagic foragers, which have lower coverage by MPAs. For example, the Atlantic puffin is listed as a species of conservation priority in Europe (European Commission, 2010) and is categorised as Endangered on the European Red List (BirdLife International, 2015); however, our results show that it has less protection than many species of Least Concern. Less than $20 \%$ of the atsea population is covered by protected areas, with only a small fraction of this contributed by SPAs. Thus, these analyses highlight the limitations of assuming that protected areas near colonies are necessarily going to serve the species that need most protection, particularly as the majority of foraging by pelagic species will occur in offshore areas (Game et al., 2009; McGowan et al., 2017). An important next step would be to assess which type of protected area (e.g. fixed or dynamic pelagic MPAs) would be more effective for these species, using additional information on foraging behaviour on a species by species basis and spatial prioritisation tools to inform future planning.

\subsection{Predictive models of seabird biodiversity}

A range of methods have been used to predict seabird distribution at sea, but all show that distance to colony is usually the most important factor (Chivers et al., 2013; Ford et al., 2007; Louzao et al., 2012; Skov et al., 2008). Some studies (see below) have explored how the use of different foraging ranges (e.g. maximum, mean maximum or mean) affects the potential accuracy of the predicted 
distributions. For gannets, Grecian et al. (2012) found that varying the foraging range used in models by $\pm 25 \%$ had no effect on how well the projected distributions correlated with at-sea survey data, and elected to use maximum foraging range in the final model. Studies by Perrow et al. (2015) and Soanes et al. (2016) suggest that the use of the mean of all maximum foraging range estimates may be more appropriate to ensure that an area proposed for conservation is not unfeasibly large. This may be true when the foraging radius approach is used to delineate a home range area $\left(\mathrm{km}^{2}\right)$ for protection, whereas for this study the final projected distributions are expressed in density of birds per grid square. The use of maximum foraging radius here allows the hotspots of highest abundance to be highlighted without completely discarding areas at the extremes of a species range where birds may still be foraging. Applying a log decay weighting to the distributions, as in step 4 of the methods, results in low densities of birds at the edge of the distributions, approaching zero individuals. Furthermore we conducted a posthoc analysis of MPA overlap using mean maximum foraging range for a short-, mid- and long-range forager, with values taken from Thaxter et al. (2012). The maximum and mean maximum overlaps were as follows: (northern gannet, $709 \mathrm{~km}$ range $=9.56 \%$ overlap and $229.4 \mathrm{~km}$ range $=12.55 \%$ overlap; black-legged kittiwake, $120 \mathrm{~km}$ range $=12.51 \%$ overlap and 60 $\mathrm{km}$ range $=13.86 \%$ overlap; common tern, $30 \mathrm{~km}$ range $=34.21 \%$ overlap and $15.2 \mathrm{~km}$ range $=$ $27.55 \%$ overlap). Thus use of maximum versus mean maximum made little difference and use of maximum values in this approach is justified.

One limitation of projection models is that they cannot account for all factors that explain where animals are found, and inevitably the predicted and true distributions will diverge. For example, density dependent segregation is likely to occur between colonies for all species (Furness \& Birkhead, 1984; Wakefield et al., 2013), and within-colony segregation between breeders, non-breeders, and juveniles, or by sex may also occur (Fayet et al., 2015; Stauss et al., 2012: Votier et al., 2017). More importantly, however, spatio-temporal variation in oceanic, meteorological, and ecological factors leads to patchy resource distribution and variable prey availability (Scales et al., 2014; Schneider, 1990; Gibb et al., 2017). These factors are likely to be especially important since they can vary within (Grémillet et al., 2008) and across (Robertson et al., 2014) years, and over long periods of time (Behrenfeld et al., 2006), issues that will also confound empirical data. Despite these limitations, however, simple projection models could be an important tool in seabird conservation for several reasons. First, dynamic oceanic and ecological factors cannot easily be included in a universal model of seabird distribution because such information is lacking for most species in most areas, even in our study area where seabirds have been studied relatively intensively. Moreover, in most cases it is unrealistic to expect these data to become available in the near future, because spatio-temporal variation is so difficult and costly to capture at any spatial scale, let alone at the scale of the marine environment for an entire community of species. Second, modifications to the model on a speciesspecific basis would need to greatly improve accuracy to be considered useful, at the cost of 
sacrificing general applicability for all species. Work to date suggests that model performance is not improved dramatically when additional data on resource abundance (Grecian et al., 2012) or bathymetric preference (Soanes et al., 2016) have been included. Third, the approach has already been shown to produce good correlations with distributions obtained from at-sea surveys or GPS tracking in a number of species in different regions (Grecian et al., 2012; Ludynia et al., 2012). Although we are only just beginning to validate our model using a variety of different kinds of empirical data (Critchley et al. in prep), visual comparison of our predictive distributions with the European Seabirds at Sea (ESAS) database outputs (Dunn, 2012; Stone et al., 1995) shows good agreement where there is sufficient coverage by ESAS. At the very least, this suggests that the foraging radius approach can be used to provide an important baseline distribution in poorly surveyed regions of the world, with the potential to include additional ecological factors where available to further refine distributions on a species by species basis. Finally, for a tool to be effective across multiple species and utilised by regulatory bodies, it should be simple to use and implement, which is true of the projection model approach.

\section{Conclusion}

The projected distribution maps generated in this study have identified both the species and areas that are currently lacking sufficient protection through establishment of protected areas during the breeding season, using a simple but universally applicable method. In particular, the combined species distributions allow us to see where hotspots with a large number of species are found, highlighting sites for further investigation. Although pelagic species are the most threatened group of seabirds globally, they were also the least well protected in our study area, where most MPAs are in coastal locations. Future assessment for marine conservation planning should account for at-sea distribution to ensure that wider-ranging seabirds are afforded sufficient levels of protection. Designation of MPAs does not per se confer protection, but appropriate management of activities within them, e.g. regulation of fisheries/petroleum exploration, can result in positive conservation outcomes at the broader ecosystem level. Utilisation of distribution maps that show hotspots of both bird density and species richness in offshore waters should enable effective conservation measures to be put in place that benefit multiple species, either through fixed or dynamic MPAs (Game et al., 2009; Hays et al., 2016). Our approach relies on good abundance estimates for individual colonies, which themselves can be extremely challenging and costly to generate. However, these challenges are likely to be considerably less than those for collecting detailed tracking or at-sea survey data, though naturally both approaches are valuable and complementary. The foraging radius method used here is therefore likely to be particularly useful in regions around the world where little data on at-sea distributions currently exist. 
343 Much of the colony data used in this study were extracted from the Seabird Monitoring Programme

344 Database [at www.jncc.gov.uk/smp]. Data have been provided to the SMP by the generous

345 contributions of nature conservation and research organisations, and of many volunteers throughout

346 the British Isles. We would like to thank Mark Bolton from RSPB, Ilka Win from JNCC and Alyn

347 Walsh from NPWS for their assistance in obtaining up to date colony data for a number of species.

348 We also thank Mark Bolton for helpful comments provided on previous versions of this manuscript,

349 and two anonymous reviewers whose comments greatly improved this manuscript. We are grateful to

350 the Irish Petroleum Infrastructure Programme for their continued support of this project, in particular

351 Martin Davies and Nick O’Neill.

352 EJC was funded by the Irish Petroleum Infrastructure Programme (PIP) IS13/08. WJG was funded by

353 INSITE http://www.insitenorthsea.org/. AK was funded by the Irish Research Council

354 GOIPD/2015/81. MJ was funded by the SFI Centre for Marine and Renewable Energy (12/RC/2302).

355 The funding bodies had no role in the study or decision to submit the paper for publication. The

356 authors have no conflicts of interest to declare. 
Ashmole, N.P., 1963. The regulation of numbers of tropical oceanic birds. Ibis, 103(3), 458-473.

Ballard, G., Jongsomjit, D., Veloz, S.D., Ainley, D.G., 2012. Coexistence of mesopredators in an intact polar ocean ecosystem: The basis for defining a Ross Sea marine protected area. Biol. Conserv. 156, 72-82. doi:10.1016/j.biocon.2011.11.017

Behrenfeld, M., O’Malley, R., Siegel, D., McClain, C., Sarmiento, J., Feldman, G., Milligan, A., Falkowski, P., Letelier, R., Boss, E., 2006. Climate-driven trends in contemporary ocean productivity. Nature 444, 752-755, doi:10.1038/nature05317

Birdlife International, 2015. European Red List of Birds. doi:10.2779/975810

BirdLife International, 2014. Marine Natura 2000 Progress Assessment.

BirdLife International, 2010. Marine Important Bird Areas toolkit: standardised techniques for identifying priority sites for the conservation of seabirds at sea.

Block, B.A., Jonsen, I.D., Jorgensen, S.J., Winship, A.J., Shaffer, S.A., Bograd, S.J., Hazen, E.L., Foley, D.G., Breed, G.A., Harrison, A.-L., Ganong, J.E., Swithenbank, A., Castleton, M., Dewar, H., Mate, B.R., Shillinger, G.L., Schaefer, K.M., Benson, S.R., Weise, M.J., Henry, R.W., Costa, D.P., 2011. Tracking apex marine predator movements in a dynamic ocean. Nature 475, 86-90. doi:10.1038/nature10082

Burke, B., Power, A., Newton, S.F., 2015. Rockabill Tern Report 2015. BirdWatch Ireland Seabird Conservation Report.

Camphuysen, K.C.J., Scott, B., Wanless, S., 2007. Distribution and foraging interactions of seabirds and marine mammals in the North Sea : a metapopulation analysis. Top Predators in Marine Ecosystems. Their Role in Monitoring and Management Conservation Biology

Chivers, L.S., Lundy, M.G., Colhoun, K., Newton, S.F., Houghton, J.D.R., Reid, N., 2013. Identifying optimal feeding habitat and proposed Marine Protected Areas (pMPAs) for the black-legged kittiwake (Rissa tridactyla) suggests a need for complementary management approaches. Biol. Conserv. 164, 73-81. doi:10.1016/j.biocon.2013.04.022

Choudhury, A., Lahiri Choudhury, D.K., Desai, A., Duckworth, J.W., Easa, P.S., Johnsingh, A.J.T., Fernando, P., Hedges, S., Gunawardena, M., Kurt, F., Karanth, U., Lister, A., Menon, V., Riddle, H., Rübel, A. \& Wikramanayake, E., 2016. The IUCN Red List Of Threatened Species [WWW Document]. Int. Union Conserv. Nat. Nat. Resour. URL http://www.iucnredlist.org/details/7140/0 (accessed 1.30.17). 
Croxall, J.P., Butchart, S.H.M., Lascelles, B., Stattersfield, A.J., Sullivan, B., Symes, A., Taylor, P., 2012. Seabird conservation status, threats and priority actions: a global assessment. Bird Conserv. Int. 22, 1-34. doi:10.1017/S0959270912000020

Daly, D., Murphy, B., Murray, T., 2015. Lady’s Island Lake Tern Report 2015. National Parks and Wildlife Service Report.

Dean, B., Kirk, H., Fayet, A., Shoji, A., Freeman, R., Leonard, K., Perrins, C., Guilford, T., 2015. Simultaneous multi-colony tracking of a pelagic seabird reveals cross-colony utilization of a shared foraging area. Mar. Ecol. Prog. Ser. 538, 239-248. doi:10.3354/meps11443

Doyle, S., Manley, P., Macey, C., Wray, J., Newton, S.F., 2015. Tern Colony Protection and Management at Kilcoole 2015. BirdWatch Ireland Seabird Conservation Report.

Dunn, T., 2012. JNCC seabird distribution and abundance data (all trips) from ESAS database [WWW Document]. OBIS-SEAMAP. URL http://seamap.env.duke.edu/dataset/427 (accessed 6.12.17).

European Commission, 2010. Directive 2009/147/EC of the European Parliament and of the Council on the conservation of wild birds. Off. J. Eur. Union L 20, 7-25.

Fayet, A.L., Freeman, R., Shoji, A., Padget, O., Perrins, C.M., Guilford, T., 2015. Lower foraging efficiency in immatures drives spatial segregation with breeding adults in a long-lived pelagic seabird. Anim. Behav. 110, 79-89. doi:10.1016/j.anbehav.2015.09.008

Ford, R.G., Ainley, D.G., Brown, E.D., Suryan, R.M., Irons, D.B., 2007. A spatially explicit optimal foraging model of Black-legged Kittiwake behavior based on prey density, travel distances, and colony size. Ecol. Modell. 204, 335-348. doi:10.1016/j.ecolmodel.2007.01.010

Furness, R.W., Birkhead, T.R., 1984. Seabird colony distributions suggest competition for food supplies during the breeding season. Nature 311, 655-656. doi:10.1038/311655a0

Game, E.T., Grantham, H.S., Hobday, A.J., Pressey, R.L., Lombard, A.T., Beckley, L.E., Gjerde, K., Bustamante, R., Possingham, H.P., Richardson, A.J., 2009. Pelagic protected areas: the missing dimension in ocean conservation. Trends Ecol. Evol. 24, 360-369. doi:10.1016/j.tree.2009.01.011

Gibb, R., Shoji, A., Fayet, A.L., Perrins, C.M., Guilford, T., Freeman, R., 2017. Remotely sensed wind speed predicts soaring behaviour in a wide-ranging pelagic seabird. J. R. Soc. Interface. doi: 10.1098/rsif.2017.0262.

Grecian, W.J., Witt, M.J., Attrill, M.J., Bearhop, S., Becker, P.H., Egevang, C., Furness, R.W., 
Godley, B.J., González-Solís, J., Grémillet, D., Kopp, M., Lescroël, A., Matthiopoulos, J., Patrick, S.C., Peter, H.-U., Phillips, R.A., Stenhouse, I.J., Votier, S.C., 2016. Seabird diversity hotspot linked to ocean productivity in the Canary Current Large Marine Ecosystem. Biol. Lett. 12, 20160024. doi:10.1098/rsbl.2016.0024

Grecian, W.J., Witt, M.J., Attrill, M.J., Bearhop, S., Godley, B.J., Grémillet, D., Hamer, K.C., Votier, S.C., 2012. A novel projection technique to identify important at-sea areas for seabird conservation: An example using Northern gannets breeding in the North East Atlantic. Biol. Conserv. 156, 43-52. doi:10.1016/j.biocon.2011.12.010

Grémillet, D., Boulinier, T., 2009. Spatial ecology and conservation of seabirds facing global climate change: a review. Mar. Ecol. Prog. Ser. 391, 121-137. doi:10.3354/meps08212

Grémillet, D., Lewis, S., Drapeau, L., Van Der Lingen, C.D., Huggett, J.A., Coetzee, J.C., Verheye, H.M., Daunt, F., Wanless, S., Ryan, P.G., 2008. Spatial match-mismatch in the Benguela upwelling zone: Should we expect chlorophyll and sea-surface temperature to predict marine predator distributions? Journal of Applied Ecology 45, 610-621. doi:10.1111/j.13652664.2007.01447.x

Halpern, B.S., Walbridge, S., Selkoe, K.A., Kappel, C., 2008. A Global Map of Human Impact on Marine Ecosystems. Science 319, 948-952. doi:10.1126/science.1149345

Hays, G.C., Ferreira, L.C., Sequeira, A.M.M., Meekan, M.G., Duarte, C.M., Bailey, H., Bailleul, F., Bowen, W.D., Caley, M.J., Costa, D.P., Eguíluz, V.M., Fossette, S., Friedlaender, A.S., Gales, N., Gleiss, A.C., Gunn, J., Harcourt, R., Hazen, E.L., Heithaus, M.R., Heupel, M., Holland, K., Horning, M., Jonsen, I., Kooyman, G.L., Lowe, C.G., Madsen, P.T., Marsh, H., Phillips, R.A., Righton, D., Ropert-Coudert, Y., Sato, K., Shaffer, S.A., Simpfendorfer, C.A., Sims, D.W., Skomal, G., Takahashi, A., Trathan, P.N., Wikelski, M., Womble, J.N., Thums, M., 2016. Key Questions in Marine Megafauna Movement Ecology. Trends Ecol. Evol. 31(6), 463-475. doi:10.1016/j.tree.2016.02.015

Hyrenbach, K.D., Forney, K. a, Dayton, P.K., 2000. Marine protected areas and ocean basin management. Aquat. Conserv. Mar. Freshw. Ecosyst. 10, 437-458. doi:10.1002/10990755(200011/12)10:6<437

IUCN and UNEP-WCMC, 2016. The World Database on Protected Areas (WDPA) [WWW Document]. Cambridge, UK UNEP-WCMC. URL www.protectedplanet.net and foraging range in seabirds. Oikos, 125(7), 968-974. 
Kot, C.Y., Fujioka, E., Hazen, L.J., Best, B.D., Read, A.J., Halpin, P.N., 2010. Spatio-temporal gap analysis of OBIS-SEAMAP project data: Assessment and way forward. PLoS One 5. doi:10.1371/journal.pone.0012990

Lascelles, B., Taylor, P., Miller, M., Dias, M.P., Oppel, S., Torres, L., Hedd, A., le Corre, M., Phillips, R.A., Scott, S., Weimerskirch, H., Small, C., 2016. Applying global criteria to tracking data to define important areas for marine conservation. Divers. Distrib. 22(4), 422-431. doi:10.1111/ddi.12411

Lascelles, B.G., Langham, G.M., Ronconi, R.A., Reid, J.B., 2012. From hotspots to site protection: Identifying Marine Protected Areas for seabirds around the globe. Biol. Conserv. 156, 5-14. doi:10.1016/j.biocon.2011.12.008

Louzao, M., Delord, K., García, D., Boué, A., Weimerskirch, H., 2012. Protecting persistent dynamic oceanographic features: Transboundary conservation efforts are needed for the critically endangered balearic shearwater. PLoS One 7. doi:10.1371/journal.pone.0035728

Ludynia, K., Kemper, J., Roux, J.P., 2012. The Namibian Islands' Marine Protected Area: Using seabird tracking data to define boundaries and assess their adequacy. Biol. Conserv. 156, 136145. doi:10.1016/j.biocon.2011.11.014

McGowan, J., Smith, R. J., Di Marco, M., Clarke, R. H. and Possingham, H. P., 2017. An Evaluation of Marine Important Bird and Biodiversity Areas in the Context of Spatial Conservation Prioritization. Conservation Letters. doi:10.1111/conl.12399

McSorley, C. A., Dean, B. J., Webb, A., \& Reid, J. B. (2003). Seabird use of waters adjacent to colonies. JNCC Report, 329.

Mitchell, P.I., Newton, S.F., Ratcliffe, N. \& Dunn, T.E., 2004, Seabird Populations of Britain and Ireland, ISBN 0713669012

Nur, N., Jahncke, J., Herzog, M.P., Howar, J., Hyrenbach, K.D., Zamon, J.E., Ainley, D.G., Wiens, J.A., Morgan, K., Balance, L.T., Stralberg, D., 2011. Where the wild things are: Predicting hotspots of seabird aggregations in the California Current System. Ecol. Appl. 21, 2241-2257. doi:10.1890/10-1460.1

Perrow, M.R., Harwood, A.J.P., Skeate, E.R., Praca, E., Eglington, S.M., 2015. Use of multiple data sources and analytical approaches to derive a marine protected area for a breeding seabird. Biol. Conserv. 191, 729-738. doi:10.1016/j.biocon.2015.08.031

R Development Core Team, 2016. R: A Language and Environment for Statistical Computing. 
Ramirez, I., Tarzia, M., Dias, M.P., Burfield, I.J., Ramos, J.A., Garthe, S. and Paiva, V.H., 2017. How well is the EU protecting its seabirds? Progress in implementing the Birds Directive at sea. Marine Policy, 81, 179-184. doi.org/10.1016/j.marpol.2017.03.034

Robertson, G.S., Bolton, M., Grecian, W.J., Monaghan, P., 2014. Inter- and intra-year variation in foraging areas of breeding kittiwakes (Rissa tridactyla). Mar. Biol. 1973-1986. doi:10.1007/s00227-014-2477-8

Rock, P., Camphuysen, C.J., Shamoun-Baranes, J., Ross-Smith, V.H. and Vaughan, I.P., 2016. Results from the first GPS tracking of roof-nesting Herring Gulls Larus argentatus in the UK. Ringing \& Migration, 31(1), 47-62. doi: 10.1080/03078698.2016.1197698

Ronconi, R.A., Lascelles, B.G., Langham, G.M., Reid, J.B., Oro, D., 2012. The role of seabirds in Marine Protected Area identification, delineation, and monitoring: Introduction and synthesis. Biol. Conserv. 156, 1-4. doi:10.1016/j.biocon.2012.02.016

Sandvik, H., Barrett, R.T., Erikstad, K.E., Myksvoll, M.S., Vikebø, F., Yoccoz, N.G., Anker-Nilssen, T., Lorentsen, S.-H., Reiertsen, T.K., Skarðhamar, J., Skern-Mauritzen, M., Systad, G.H., 2016. Modelled drift patterns of fish larvae link coastal morphology to seabird colony distribution. Nat. Commun. 7, 11599. doi:10.1038/ncomms11599

Scales, K.L., Miller, P.I., Embling, C.B., Ingram, S.N., Pirotta, E., Votier, S.C., 2014. Mesoscale fronts as foraging habitats: composite front mapping reveals oceanographic drivers of habitat use for a pelagic seabird. J. R. Soc. Interface 11, 20140679. doi:10.1098/rsif.2014.0679

Schneider, D.C., 1990. Seabirds and fronts: a brief overview. Polar Res. 8, 17-21. doi:10.1111/j.17518369.1990.tb00370.x

Secretariat of the Convention on Biological Diversity, 2014. Global Biodiversity Outlook 4.

Skov, H., Humphreys, E., Garthe, S., Geitner, K., Grémillet, D., Hamer, K.C., Hennicke, J., Parner, H., Wanless, S., 2008. Application of habitat suitability modelling to tracking data of marine animals as a means of analyzing their feeding habitats. Ecol. Modell. 212, 504-512. doi:10.1016/j.ecolmodel.2007.11.006

Soanes, L.M., Bright, J.A., Angel, L.P., Arnould, J.P.Y., Bolton, M., Berlincourt, M., Lascelles, B., Owen, E., Simon-Bouhet, B., Green, J.A., 2016. Defining marine important bird areas: Testing the foraging radius approach. Biol. Conserv. 196, 69-79. doi:10.1016/j.biocon.2016.02.007

Stone, C., Webb, A., Barton, C., Ratcliffe, N., Reed, T., Tasker, M., Camphuysen, C.J., Pienkowski, M., 1995. An atlas of seabird distribution in north-west European waters, An atlas of seabird 
distribution in north-west European waters. Joint Nature Conservation Committee.

516

Thaxter, C.B., Daunt, F., Grémillet, D., Harris, M.P., Benvenuti, S., Watanuki, Y., Hamer, K.C., Wanless, S., 2013. Modelling the effects of prey size and distribution on prey capture rates of two sympatric marine predators. PLoS One 8. doi:10.1371/journal.pone.0079915

Thaxter, C.B., Lascelles, B., Sugar, K., Cook, A.S.C.P., Roos, S., Bolton, M., Langston, R.H.W., Burton, N.H.K., 2012. Seabird foraging ranges as a preliminary tool for identifying candidate Marine Protected Areas. Biol. Conserv. 156, 53-61. doi:10.1016/j.biocon.2011.12.009

UNEP-WCMC and IUCN, 2016. Protected Planet Report 2016. Cambridge UK and Gland, Switzerland.

Votier, S.C., Fayet, A.L., Bearhop, S., Bodey, T.W., Clark, B.L., Grecian, J., Guilford, T., Hamer, K.C., Jeglinski, J.W., Morgan, G. and Wakefield, E., 2017. Effects of age and reproductive status on individual foraging site fidelity in a long-lived marine predator. Proc. R. Soc. B, 284(1859), p.20171068.

Wakefield, E.D., Bodey, T.W., Bearhop, S., Blackburn, J., Colhoun, K., Davies, R., Dwyer, R.G., Green, J. a, Grémillet, D., Jackson, A.L., Jessopp, M.J., Kane, A., Langston, R.H.W., Lescroël, A., Murray, S., Le Nuz, M., Patrick, S.C., Péron, C., Soanes, L.M., Wanless, S., Votier, S.C., Hamer, K.C., 2013. Space partitioning without territoriality in gannets. Science (80-. ). 341, 6870. doi:10.1126/science. 1236077

Wakefield, E.D., Owen, E., Baer, J., Carroll, M.J., Daunt, F., Dodd, S.G., Green, J.A., Guilford, T., Mavor, R.A., Miller, P.I., Newell, M.A., Newton, S.F., Robertson, G.S., Shoji, A., Soanes, L.M., Votier, S.C., Wanless, S., Bolton, M., 2017. Breeding density, fine-scale tracking and large-scale modeling reveal the regional distribution of four seabird species. Ecol. Appl. doi:10.1002/eap.1591

Watson, J.E.M., Dudley, N., Segan, D.B., Hockings, M., 2014. The performance and potential of protected areas. Nature 515, 67-73. doi:10.1038/nature13947\r

Wickham, H., 2009. ggplot2: Elegant Graphics for Data Analysis. Springer-Verlag New York.

Wilson, L.J., McSorley, C.A., Gray, C.M., Dean, B.J., Dunn, T.E., Webb, A., Reid, J.B., 2009. Radiotelemetry as a tool to define protected areas for seabirds in the marine environment. Biol. Conserv. 142, 1808-1817. doi:10.1016/j.biocon.2009.03.019 


\section{Table 1}

Summary for each species of the number of colonies in Britain and Ireland; total population size (individuals) from most recent colony counts; European conservation status; proportion of the European population contained in Britain and Ireland; maximum foraging range $(\mathrm{km})$; and foraging range group (pelagic or coastal). European conservation status is taken from the IUCN Red List of Threatened Species (Choudhury et al., 2016). European population size was taken as the maximum estimate from the IUCN (Choudhury et al., 2016). The proportion estimated is therefore the minimum potential percentage of the biogeographical population contained in Britain and Ireland. Maximum foraging range was taken from a review by Thaxter et al. (2012) with a few exceptions, see table footnotes. Species with a maximum foraging range of less than $75 \mathrm{~km}$ were defined as coastal and those with a maximum foraging range of $75 \mathrm{~km}$ or greater were defined as pelagic.

\begin{tabular}{|c|c|c|c|c|c|c|}
\hline Species & $\begin{array}{l}\text { Number } \\
\text { of } \\
\text { colonies }\end{array}$ & $\begin{array}{l}\text { Population } \\
\text { size } \\
\text { (individuals) }\end{array}$ & $\begin{array}{l}\text { European } \\
\text { conservation } \\
\text { status }\end{array}$ & $\begin{array}{l}\text { Proportion of } \\
\text { European } \\
\text { population }(\%)\end{array}$ & $\begin{array}{l}\text { Maximum } \\
\text { foraging } \\
\text { range }(\mathrm{km})\end{array}$ & $\begin{array}{l}\text { Foraging } \\
\text { range } \\
\text { group }\end{array}$ \\
\hline $\begin{array}{l}\text { Arctic skua } \\
\text { Stercorarius parasiticus }\end{array}$ & 643 & 4740 & Least concern & 4.23 & 75 & Pelagic \\
\hline $\begin{array}{l}\text { Arctic tern } \\
\text { Sterna paradisaea }\end{array}$ & 959 & 116472 & Least concern & 6.43 & 30 & Coastal \\
\hline $\begin{array}{l}\text { Atlantic puffin } \\
\text { Fratercula arctica }\end{array}$ & 405 & 869690 & Endangered & 7.50 & 200 & Pelagic \\
\hline $\begin{array}{l}\text { Black guillemot } \\
\text { Cepphus grylle }\end{array}$ & 1323 & 38529 & Least concern & 5.19 & $15^{\mathrm{c}}$ & Coastal \\
\hline $\begin{array}{l}\text { Black-headed gull }^{\mathrm{a}} \\
\text { Larus ridibundus }\end{array}$ & 415 & 184240 & Least concern & 7.44 & 40 & Coastal \\
\hline $\begin{array}{l}\text { Black-legged kittiwake } \\
\text { Rissa tridactyla }\end{array}$ & 538 & 704028 & Vulnerable & 15.96 & 120 & Pelagic \\
\hline $\begin{array}{l}\text { Common guillemot } \\
\text { Uria aalge }\end{array}$ & 506 & 1271624 & $\begin{array}{l}\text { Near } \\
\text { threatened }\end{array}$ & 41.56 & 135 & Pelagic \\
\hline $\begin{array}{l}\text { Common gull } \\
\text { Larus canus }\end{array}$ & 1330 & 48110 & Least concern & 4.76 & 50 & Coastal \\
\hline $\begin{array}{l}\text { Common tern } \\
\text { Sterna hirundo }\end{array}$ & 376 & 35468 & Least concern & 3.11 & 30 & Coastal \\
\hline $\begin{array}{l}\text { European shag } \\
\text { Phalacrocorax aristotelis }\end{array}$ & 1238 & 61798 & Least concern & 39.36 & 17 & Coastal \\
\hline $\begin{array}{l}\text { European storm-petrel } \\
\text { Hydrobates pelagicus }\end{array}$ & 107 & 178138 & Least concern & 17.29 & $336^{d}$ & Pelagic \\
\hline $\begin{array}{l}\text { Great black-backed gull } \\
\text { Larus marinus }\end{array}$ & 2010 & 36528 & Least concern & 13.73 & $60^{\mathrm{c}}$ & Coastal \\
\hline $\begin{array}{l}\text { Great cormorant }{ }^{\mathrm{b}} \\
\text { Phalacrocorax carbo }\end{array}$ & 290 & 27084 & Least concern & 3.00 & 35 & Coastal \\
\hline
\end{tabular}




\begin{tabular}{|c|c|c|c|c|c|c|}
\hline $\begin{array}{l}\text { Great skua } \\
\text { Stercorarius skua }\end{array}$ & 700 & 16016 & Least concern & 46.42 & 219 & Pelagic \\
\hline $\begin{array}{l}\text { Herring gull } \\
\text { Larus argentatus }\end{array}$ & 2633 & 278340 & $\begin{array}{l}\text { Near } \\
\text { threatened }\end{array}$ & 17.82 & 92 & Pelagic \\
\hline $\begin{array}{l}\text { Leach's storm-petrel } \\
\text { Oceanodroma leucorhoa }\end{array}$ & 16 & 96714 & Least concern & 17.68 & 120 & Pelagic \\
\hline $\begin{array}{l}\text { Lesser black-backed gull } \\
\text { Larus fuscus }\end{array}$ & 907 & 180790 & Least concern & 26.79 & 181 & Pelagic \\
\hline $\begin{array}{l}\text { Little tern } \\
\text { Sterna albifrons }\end{array}$ & 63 & 3424 & Least concern & 3.23 & 11 & Coastal \\
\hline $\begin{array}{l}\text { Manx shearwater } \\
\text { Puffinus puffinus }\end{array}$ & 43 & 658798 & Least concern & 83.92 & 330 & Pelagic \\
\hline $\begin{array}{l}\text { Mediterranean gull }{ }^{\mathrm{a}} \\
\text { Larus melanocephalus }^{2}\end{array}$ & 16 & 1026 & Least concern & 0.16 & 20 & Coastal \\
\hline $\begin{array}{l}\text { Northern fulmar } \\
\text { Fulmarus glacialis }\end{array}$ & 2643 & 1075514 & Endangered & 15.36 & 580 & Pelagic \\
\hline $\begin{array}{l}\text { Northern gannet } \\
\text { Morus bassanus }\end{array}$ & 27 & 576088 & Least concern & 42.05 & $709^{e}$ & Pelagic \\
\hline $\begin{array}{l}\text { Razorbill } \\
\text { Alca torda }\end{array}$ & 679 & 178773 & $\begin{array}{l}\text { Near } \\
\text { threatened }\end{array}$ & 17.53 & 95 & Pelagic \\
\hline $\begin{array}{l}\text { Roseate tern } \\
\text { Sterna dougallii }\end{array}$ & 5 & 3060 & Least concern & 52.76 & 30 & Coastal \\
\hline $\begin{array}{l}\text { Sandwich tern } \\
\text { Sterna sandvicensis }\end{array}$ & 64 & 34166 & Least concern & 11.58 & 54 & Coastal \\
\hline
\end{tabular}

${ }^{a}$ Gull colonies that were located at a distance of greater than $5 \mathrm{~km}$ from the coast were classified as inland, following criteria set out by Mitchell et al. (2004) and excluded from analysis.

${ }^{\mathrm{b}}$ For common tern and great cormorant a number of colonies were located at a distance greater than the maximum foraging range; these were excluded from analysis.

${ }^{c}$ Maximum foraging range taken from review by Jovani et al. (2015)

${ }^{\mathrm{d}}$ Maximum foraging range taken from unpublished GPS tracking data from High Island, Co. Galway, Ireland (Kane, A., Pers. Comm.)

${ }^{\mathrm{e}}$ Maximum foraging range taken from Wakefield et al. (2013) 
Table 2 Results of Wilcoxon rank sum tests to assess differences in percentage overlap for (1) foraging group (Coastal or Pelagic) and (2) conservation status (Least Concern or Near Threatened and above). Significant results are shown in bold. Mean percentage overlap contained within SPAs, OSPAR MPAs and all PAs combined is shown for each group.

$\%$ overlap with predicted distributions

$\%$ overlap with predicted distributions

\begin{tabular}{llllllll} 
Foraging group & SPAs & OSPAR MPAs & All PAs & Conservation status & SPAs & OSPAR MPAs & All PAs \\
\hline Coastal & $18.13 \%$ & $25.45 \%$ & $32.49 \%$ & Least Concern & $12.45 \%$ & $20.27 \%$ & $25.04 \%$ \\
Pelagic & $2.43 \%$ & $11.89 \%$ & $13.21 \%$ & Threatened & $2.11 \%$ & $12.48 \%$ & $14.29 \%$ \\
\hline & Result of Wilcoxon Rank Sum test (p-value) & & \multicolumn{2}{l}{ Result of Wilcoxon Rank Sum test (p-value) } \\
\hline coastal > pelagic & $<\mathbf{0 . 0 0 1}$ & $\mathbf{0 . 0 0 1 2}$ & $<\mathbf{0 . 0 0 1}$ & least concern $>$ threatened & $\mathbf{0 . 0 1}$ & 0.09 & 0.07 \\
\hline
\end{tabular}


a
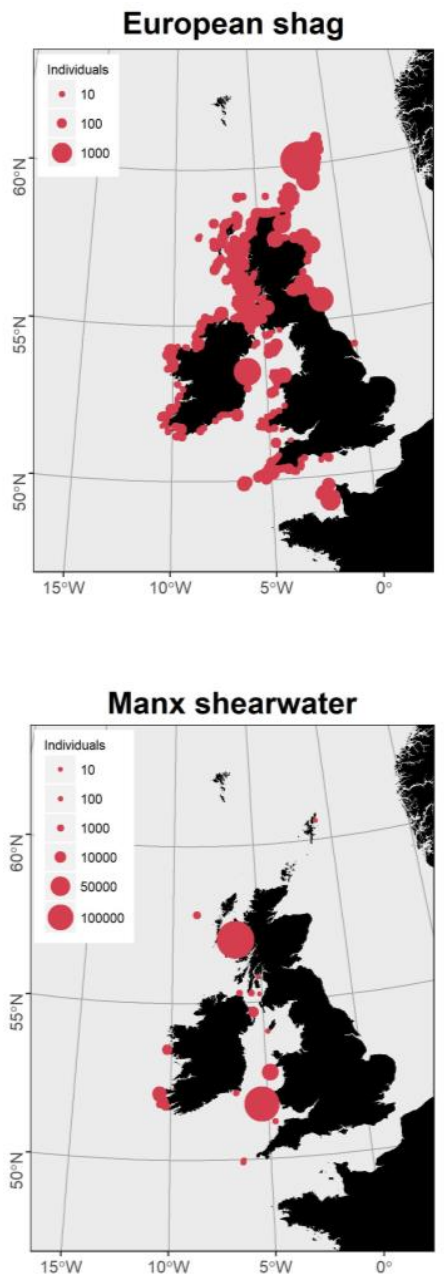

b
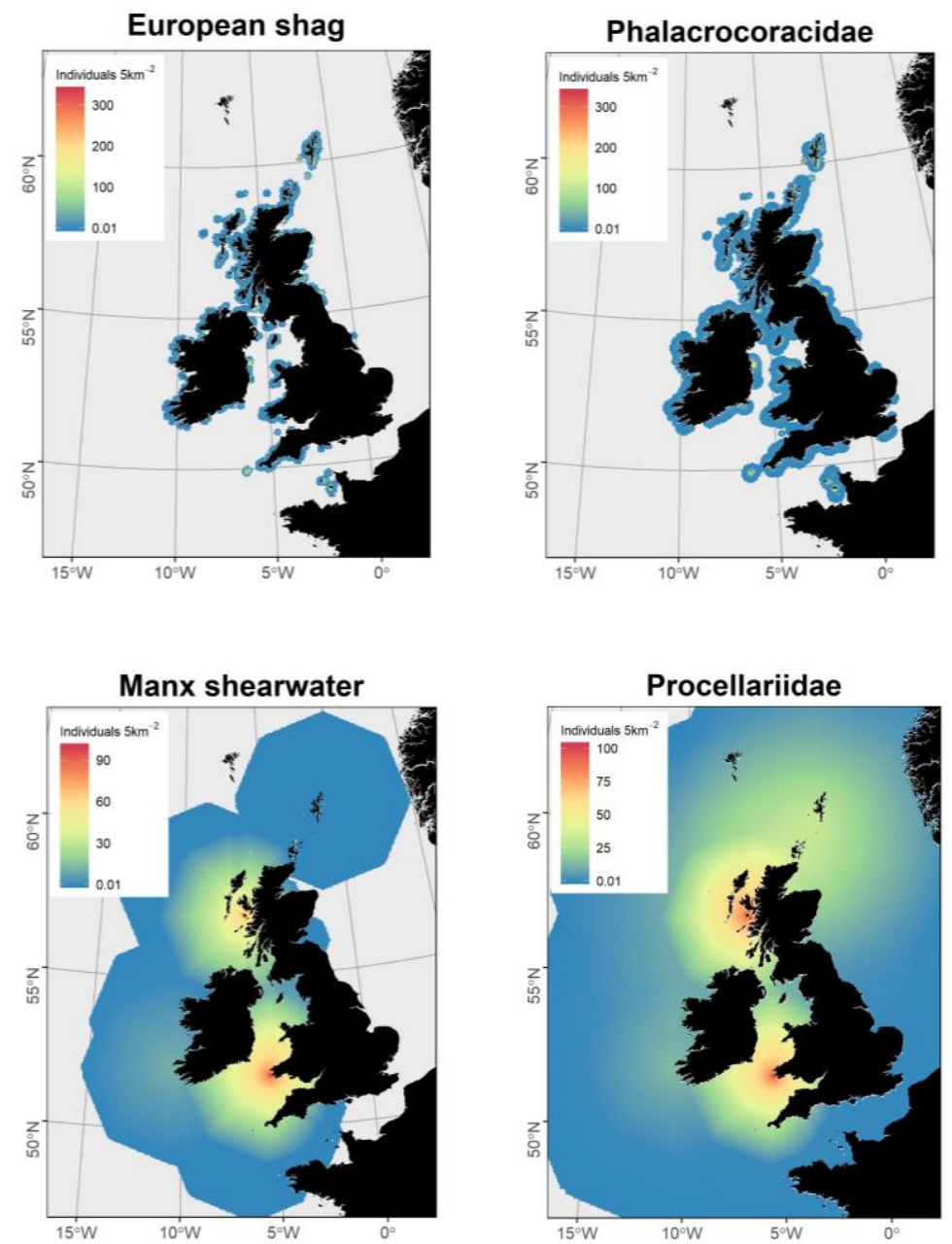

Figure 1 Maps for example coastal (Phalacrocoracidae) and pelagic (Procellariidae) family groups occurring in Britain and Ireland showing a) colony location and population size for a sample species, b) projected at-sea distributions for a sample species, and c) projected at-sea distribution for the family group. Maps for all species and groups can be found in Figures A.1, A.2 and A.3 in the supplementary material. Details of the species contained within each family group can be found in Table B.2 

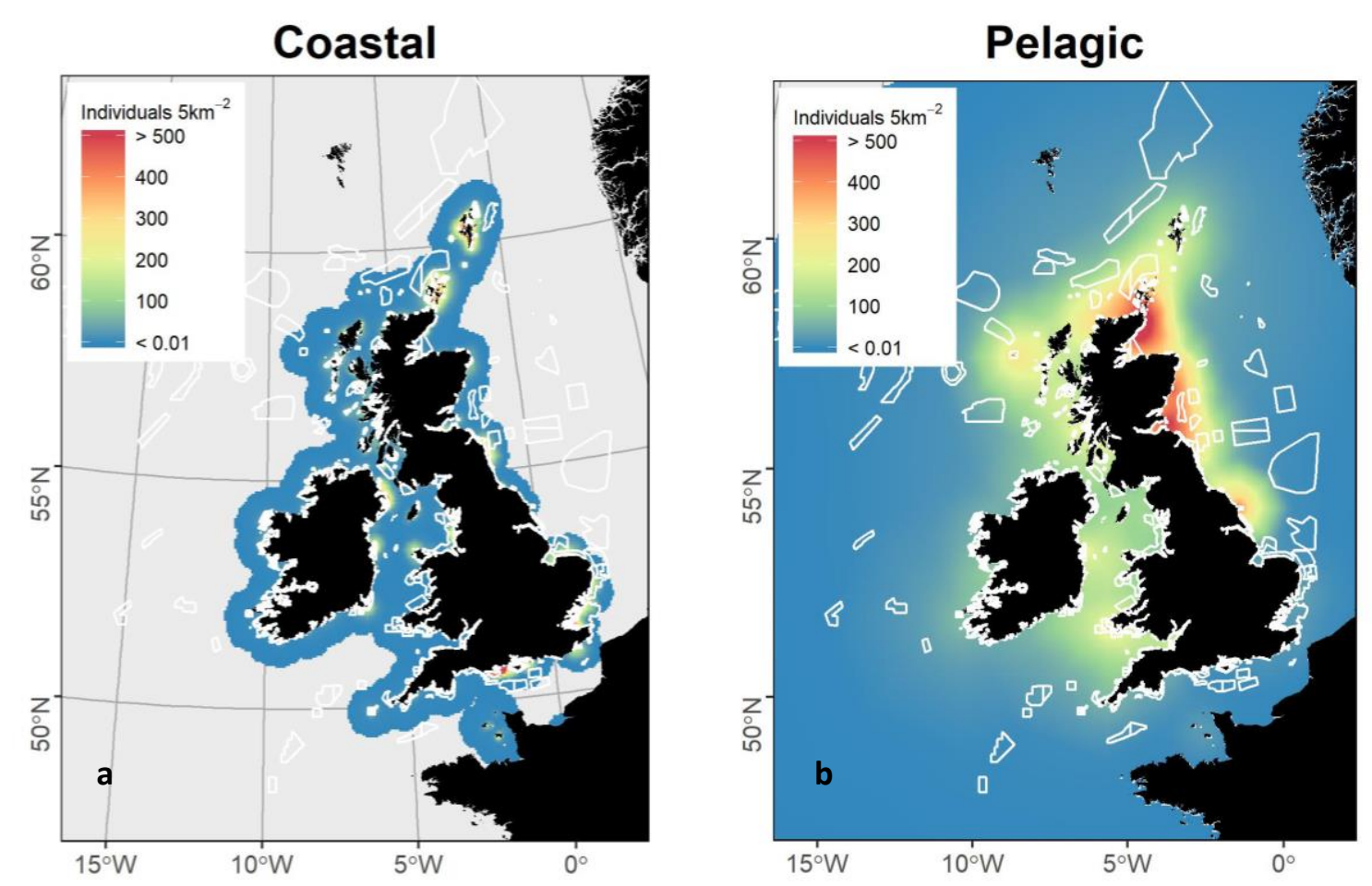

Figure 2 Maps showing the projected distributions for a) all coastal species and b) all pelagic species, with protected areas overlaid (white polygons). The colour scale shows predicted density (individuals per $5 \times 5 \mathrm{~km}$ square) if $50 \%$ of the colony is at-sea at a given time, and values are consistent across both maps. Grid squares with over 500 individuals are red and grid squares containing less than 0.01 are blue. 


\section{Species richness}

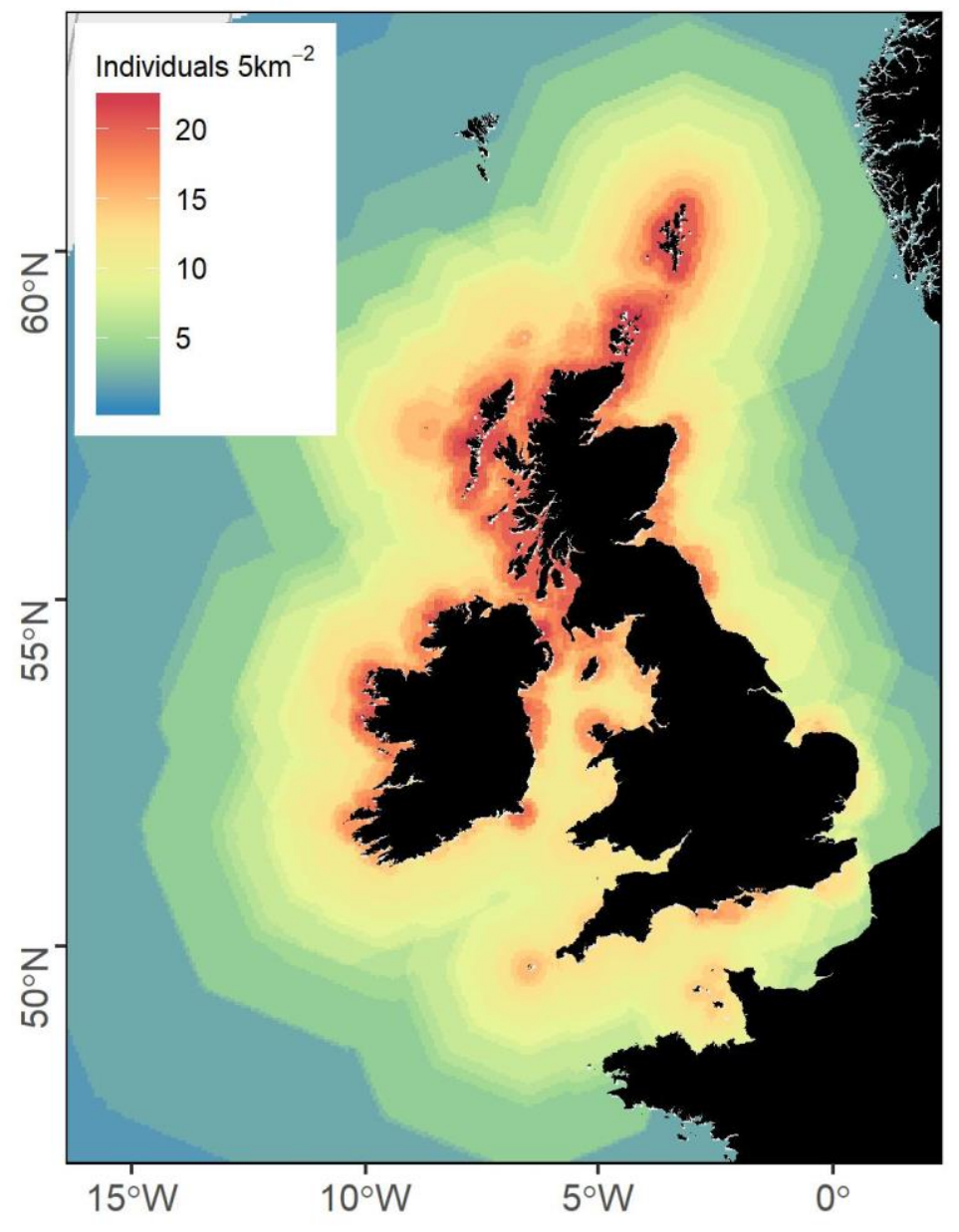

Figure $3 \mathrm{~A}$ map of species richness showing the potential number of species occurring within each $5 \times 5 \mathrm{~km}$ grid square based on the projected distribution for all species combined. 


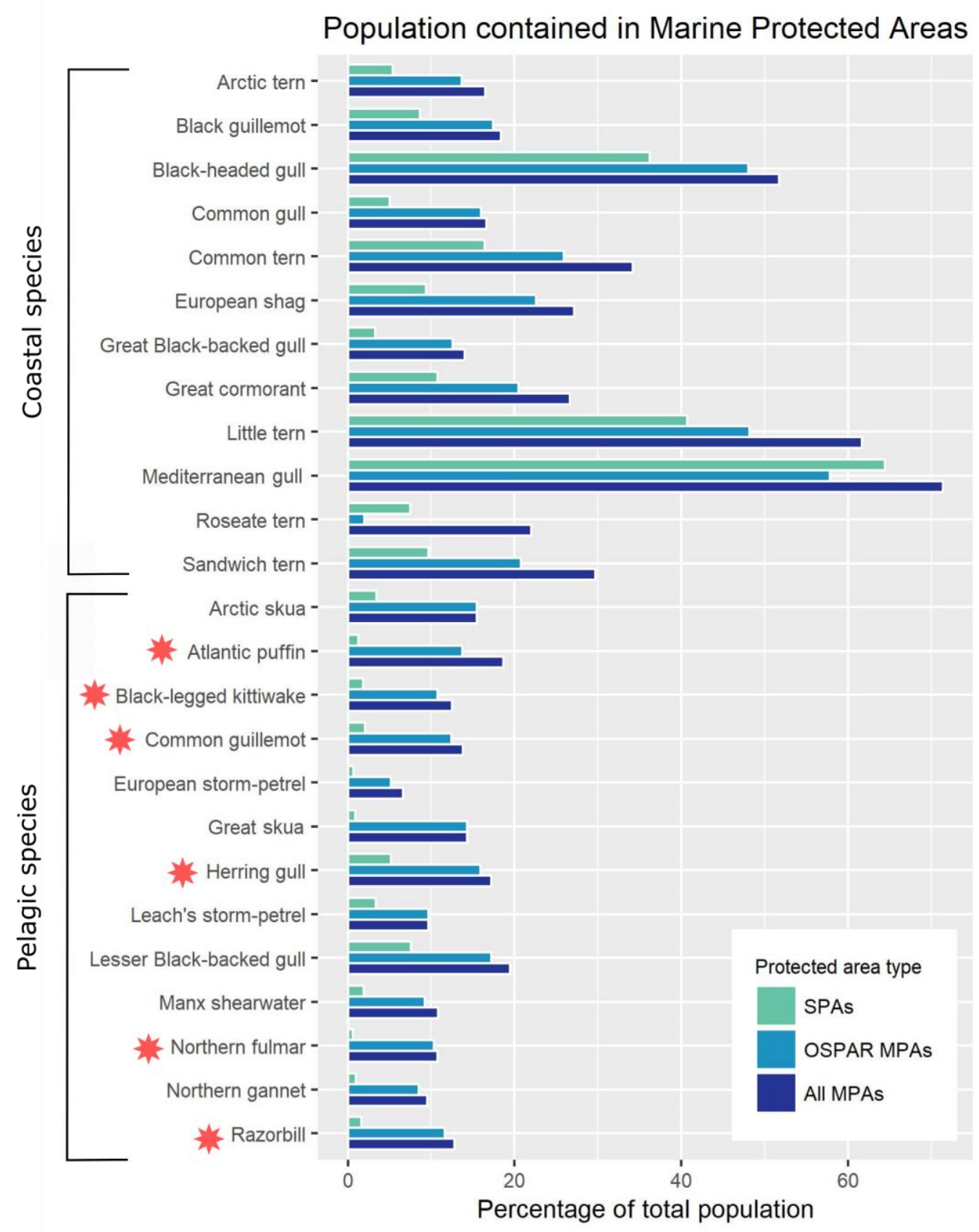

Figure 4 Percentage of predicted at-sea population contained within a currently designated protected area for: green $=$ Special Protected Areas (SPAs); light blue = OSPAR Marine Protected Areas; and navy blue = All protected areas combined. Red stars indicate species that have a European Conservation status of 'Near threatened' or higher. Percentage values are not additive as there is spatial overlap between the different protected area types. See Table B.1 in the supplementary material for a complete list of the percentage values. 